\title{
Willingness to Pay Additional Water Rate and Irrigation Knowledge of Farmers in Dinar Karakuyu Irrigation Areas in Turkey"
}

\author{
Mevlüt Gül $^{1 *}$, Kutlan Uzunkaya ${ }^{2}$ \\ ${ }^{I}$ Department of Agricultural Economics, Faculty of Agriculture, Suleyman Demirel University, 32260 Isparta, Turkey \\ ${ }^{2}$ General Directorate of State Hydraulic Works, The Second Regional Directorate, 35100 Bornova Izmir, Turkey
}

A R T I C L E I N F O
${ }^{\#}$ This study is a part of the Kutlan
Uzunkaya's postgraduate thesis. Mevlüt
Gül is a supervisor.

Research Article

Received 18 January 2017

Accepted 15 Nisan 2017

\section{Keywords: \\ Irrigation \\ Logit \\ Willingness \\ Knowledge \\ Turkey}

\begin{tabular}{l}
\hline Corresponding Author: \\
\hline E-mail: mevlutgul@sdu.edu.tr
\end{tabular}

\begin{abstract}
A B S T R A C T
Water which has become commodity product which is an important product today. Turkey is not a water rich country. In this study, agricultural enterprises in the field of Irrigation Project in Dinar Karakuyu which was implemented in 1992 by DSI. The study analysed which factors affect the willingness to pay additional irrigation water rate with the help of logit model and the irrigation knowledge of farmers was determined by Likert scale. Dinar Karakuyu irrigation network has begun to lose the function in the region. It was supposed $100 \%$ irrigation rate but decreased by approximately $9 \%$ today. In this context, DSI (General Directorate of State Hydraulic Works) plans to rehabilitation work in the same area. The main material of this study was data obtained from 67 agricultural enterprises through a survey covered by the Irrigation Rehabilitation Project in the province of Afyonkarahisar Karakuyu Dinar. The data was gathered with the help of questionnaires which were answered by farmers in Karakuyu Dinar region. The results indicated that $74.6 \%$ of farmers were willingness to pay additional water charge. The data were statistically analysed with the use of the logit model. The model results show that agricultural income, farmers' educational level, computer ownership, attendance of agricultural training activities, family size and agricultural experience were positive factors affect farmers' willingness to pay additional water fee.
\end{abstract}

DOI: https://doi.org/10.24925/turjaf.v5i8.888-897.1166

\section{Introduction}

Agricultural production is one of the irreplaceable economic activities for both Turkey and the world. The agricultural activities were conducted in different ways and the economic gains of the farms were determined by these different activities. The income levels of the agricultural farms were directly influenced by the fact whether irrigated or dry farming is implemented. This situation is not only valid for the vegetable production but also for the farms involved in livestock or mixed production activities. If there is water, the revenue is high and if there is not water, the revenue is low. Turkey is not a water-rich country. According to the annual amount of water available per person, Turkey is a country with water scarcity. An annual amount of water available per capita is around $1519 \mathrm{~m}^{3}$ (DSI, 2013).

The irrigation project field is situated within the borders of Afyonkarahisar - Dinar district's boundaries. At the same time, the field is at the upper basin of Büyük Menderes river. The basin is neighbour to Büyük Menderes basin on the west, Çöl plain and Uluborlu plain on the east, Ekin plain on the north and Burdur plain on the south, respectively. The drainage area is $382 \mathrm{~km}^{2}$.
General Directorate of State Hydraulic Works moves with the assumption of $100 \%$ irrigation during irrigation investments planning. However, the irrigation rate of Dinar Karakayu is remarkably different from the assumed irrigation rate. The irrigation rate of Dinar Karakayu dropped to approximately $11 \%$.

Despite the active management of the Dinar Union of Village Delivery Service, the renovation cannot be completed due to the lack of finance for the maintenance and renovation work, construction of Karakuyu irrigation systems based on canalette system which is not produced any more. Excessive water consumption due to shortcomings of maintenance and renovation of the Karakuyu irrigation is the main problem. The efficiency of Karakuyu irrigation fluctuated between $14.95 \%$ as the minimum and $43.76 \%$ the maximum efficiency between 2009-2013. In irrigation season, the amount of water taken to the network is directly affected by energy costs due to the performance of irrigation pumping. Irrigation efficiency has followed a fluctuating course since it started serving the farms in Karakuyu due to the effect of water requirement of products on the size of irrigated area, network deficiencies, maintenance activities and 
influence of the previous year's market prices over the product variety. In this context, General Directorate of State Hydraulic Works has planning the rehabilitation work in the same area.

This study aimed to point out the Afyonkarahisar Dinar Karakuyu Irrigation, which was chosen as the sample case of the study, on agricultural enterprises after the Irrigation Rehabilitation work.

The irrigation knowledge and awareness level of farmers is considerably important in farms where water is extremely important. Besides knowledge and awareness of water use, socio-economic characteristics constitute another important factor group in the decision making process of farmers. Individuals were affected from the external environment in decision-making process and behaviour creation and they make a decision by considering this influence and their own experiences. This interaction's influence was investigated on the farmer's willingness to pay additional water rate in DinarKarakuyu irrigation area. The socio-economic factors influencing the willingness to pay was attempted to be pointed out through various researches.

Eren et al. (2008) found out in their study called "Factors Influencing the Pricing of Potable Water in GAP Region" that the households were willing to pay 6 TL (‡) for the healthy potable water. The factors influencing the willingness to pay were determined to be "household head's monthly income, household head's education level, price offered to the household for potable water, and household's use of dispenser sized bottle water.

Çınar and Armağan (2009) conducted probit analysis in their study called "Determination of Prices that Farmers were Willing to Pay for Agricultural Extension and Counselling Services: Aydin Sample" in order to determine the price that farmers were willing to pay to the private enterprises which get involved in the agricultural extension and counselling services regulated by 5488 numbered Agricultural Law.

Aydoğdu et al. (2014) pointed out in their study called "Pricing Trends in Agricultural Irrigation; Farmers' Attitudes and Perceptions towards Pricing; GAP-Harran Plain Irrigation, Şanlıurfa" that farmers agreed that there needed to be a price for farmers' economic and effective use of water. The ratio of farmers believing that water should be priced was 55\%, 23\% considered water's being priced normal, $15 \%$ agreed it partially and $7 \%$ disagreed with water's being priced. The majority of farmers considered water's being priced normal but there were some farmers who considered the price of water high. It was found out that there were 2.6 times water price difference between farmers, who considered water price high and farmers irrigating in pumped irrigation areas and irrigating by gravity.

Aydoğdu et al. (2015) informed in their study called 'Irrigation Union Heads' View of Water Pricing and Managership: Irrigation Sample of GAP-Harran Plain" that farmers' demands and irrigation operating costs were not taken into consideration in the pricing of irrigation water. They recommended for a sustainable water management that the pricing needed to cover the minimum operating costs and the determined prices needed to be within farmers' ability to pay.

Therefore, the farmers' willingness to pay additional water rate after rehabilitation of irrigation system and socio-economic factors influencing the willingness to pay were aimed to be determined in Karakuyu irrigation area in Afyonkarahisar.

\section{Material and Method}

The main material of this study's data was collected from agricultural enterprises by the survey in the Irrigation Rehabilitation Project of Karakuyu Dinar in the Afyonkarahisar province. Additionally, it was benefited from the relevant researches conducted at national and international level. The acquired data represents the 2013 production term.

The sample volume interviewed according to the Stratified Sampling Method (Yamane, 2001) consists of 67 farmers with $10 \%$ error margin and 95\% confidence limit. The "Neyman Method" was used in the distribution of sample farms into the layers (Çiçek and Erkan, 1996).

The optimum sample volume was determined as 67 farms and these farms were divided into four groups according to the farm size. Accordingly, group I consists of farms having 1-25 decares farm size (17 farms), group II consists of farms having 25.1-50 decares farm size(13 farms), group III consists of farms having 50.1-100 decares land size (20 farms) and group IV consists of farms owning 100.1 or more decares land size (17 farms) (Table 1).

The project area is located in Isparta General Directorate of State Hydraulic Works 18th Regional Directorate's jurisdiction. It was aimed to irrigate gross 4424 ha, net 3860 hectares area through pumped irrigation and irrigation by gravity with the existing irrigation facility which started to operate in 1991. Dinar Karakuyu irrigation started to operate as two different irrigation area and irrigation by gravity was rehabilitated. This study covers the pumped irrigation part of Karakuyu Irrigation.

The water used, knowledge and awareness levels were determined through questions prepared in 5-point Likert scale in the study. This scale aims to classify or grade the notions of individuals about one product or event in a range: Totally agree, totally disagree, accept, strongly reject.

The socio-economic factors influencing the willingness to pay water price was determined by analysing the data obtained through Logistic Regression Model.

The data regarding the studied event in applied social sciences are generally classified data with discrete value. The main focus of the logistic regression analysis is to create a regression equation that can be used to locate individuals in classifications (Çokluk et al., 2014).

The logistic regression model tied to cumulative logistic distribution function is expressed as given below (Gujarati and Porter, 2009). 
Table 1 Sample Size

\begin{tabular}{l|cccc}
\hline \multicolumn{1}{c|}{ Farm groups } & Decare & $\mathrm{N}$ & Average size (da) & $\mathrm{n}$ \\
\hline I & $1.0-25.0$ & 381 & 12.40 & 17 \\
II & $25.1-50.0$ & 179 & 35.60 & 13 \\
III & $50.1-100.0$ & 96 & 69.00 & 20 \\
IV & 100.1 & 21 & 151.50 & 17 \\
\hline Total & & 677 & 28.60 & 67 \\
\hline
\end{tabular}

$$
P i=\frac{1}{1+e^{-Z i}}
$$

$P_{\mathrm{i}} \quad$ : Selection possibility,

$$
Z_{i}=\beta 0+\ldots+\beta i X i
$$

$\beta_{0} \quad$ : Constant coefficient

$\beta_{\mathrm{i}} \quad$ : Estimated parameters

$\mathrm{X}_{\mathrm{i}} \quad$ : i numbered independent variable

The odds ratio is determined by comparing the selection possibility to non-selection possibility. Logit value is obtained by taking the natural logarithm of odds.

$$
Z i=\operatorname{Ln}\left(\frac{\mathrm{Pi}}{1-\mathrm{Pi}}\right)={ }_{0}+{ }_{0}{ }_{1} X_{1}+{ }_{2} X_{2}+\ldots+{ }_{i} X_{i}+u_{i}
$$

The independent variable coefficients obtained through regression model expresses how the logarithm of odds ratio changes in case of a change of one unit in independent variable and „u“ as the error term of the model is added to the equation. In other words, the coefficients obtained from Logit model indicate the possibility of selecting one event to not selecting (Gül et al., 2012).

\section{Results and Discussion}

\section{Farmers View of Water}

The irrigated land ownership of the studied farms was 1.59 decare, 8.97 decare, 41.50 decare and 81.41 decare for farm size groups respectively. It was reported in General Directorate of State Hydraulic Works Operation and Maintenance Assessment Report that irrigation rate was over $11.02 \% .33 .17 \%$ of the 35.20 decare field per farm can be irrigated in the region. The share of irrigated field increases in parallel with the farm size groups. The share of owned land is $82.62 \%$ and rented land is $17.38 \%$ at average. The share of owned land was higher in small farms.

The farmers were demanded to grade their preference, attitude, judgment and awareness levels about the irrigation in accordance with (1) quite insignificant and (5) quite significant scale.

The answers regarding the efficacy of modern pressure irrigation system for irrigation labour changes between 4.41 and 5.00. It was seen that the farmers totally agrees with the fact that pressure irrigation system has an effect on irrigation labour. The influence of pressure irrigation system on water use was graded between 4.65 and 4.92 . Therefore, farmers totally agrees with the fact that pressure irrigation system has an effect and advantage on water use. The influence of pressure irrigation system on irrigation cost was graded between 4.75 and 5.00 and farmers totally agree with the fact that pressure irrigation system has a remarkable effect on irrigation cost. Farmers totally disagree with the idea that irrigation system has an effect on product quality, productivity and total cost (Table 2).

It was seen that the knowledge and experience of relatives, acquaintances and farmers were important in materials selection for irrigation system. The knowledge and experience of farmers in the studied farms have a significance level between 4.12 and 4.69. It was found out that the recommendations of technical staff, written sources, suppliers and dealers of agricultural materials had a low effect on material selection for irrigation system. The technical staff, suppliers and dealers were graded between 2 and 4 out of 5 by the studied farmers. Therefore, it can be said that their influence on material selection was extremely low and insignificant (Table 3).

While group I and IV farms were irresolute whether there was water problem in the region, group II and III farms consider that there was water problem in the region. While group I and IV farms were irresolute whether there will be water problem in the future in the region, group II and III farms consider that there will be water problem in the region. While group I, II and III farms agree with the "water is scarce" statement, group IV farms were irresolute. All groups agree with the statement that water is very valuable. Additionally, all groups agree with the idea that water resources were diminishing in the region (Table 4).

\section{Awareness of Water Use}

Farmers shape the product design in accordance with water sources. The products suitable to dry farming were preferred in the regions which were far away from the water or lack irrigation projects. The products suitable to irrigated farming were preferred in the regions that can be irrigated except extraordinary situations. The existence of sufficient water for irrigated farming leads to the development of irrigation culture.

According to the farms' average, the farmers totally agree with the following statements; "new irrigation system provides savings", "producers should join farms", "producers should protect supply network", "water should not be wasted", "I warn in case of the wasted water", "plenty of water increases diseases and pests", "I know products' time of irrigation." Farmers agree with the following statements; "water is mostly used in agriculture", "unconscious irrigation is done", "I know 
the water need of the products", "I know the irrigation system suitable to my field" and "I do constrained irrigation if necessary."

Farmers totally disagree with the following statements; "over water use does not damage the soil" and "surface irrigation is the best method" (Table 5).

\section{Water Saving and Farmer}

Considering the factors influencing water saving at farms average, planned water distribution was graded 4.70 , irrigation training 4.60, application of technology to agriculture 4.61, respectively. Farmers agree that control mechanism in irrigation fields should be increased and placing recorded at the beginning of parcels could provide water saving and they were irresolute about whether legal punishments and increases in irrigation water price would lead to water saving (Table 6).
The Influence of Socioeconomic Features on The Willingness To Pay Water Price

The Logit model was used to determine socioeconomic factors influencing the willingness to pay.

The obtained data was calculated with SPSS statistical package program. In this model, the dependent variable was the acceptance to pay water price and dependent variable $0=$ acceptance, $1=$ non-acceptance. In the model, following socioeconomic features were considered as independent variables; household size, land ownership, computed ownership, operation debt per decare, newspaper reading status, social security status, water price payment status, agricultural income per decade, education level of farmer, agricultural training, agricultural experience time, membership time to producer unions.

Table 2 The effects of irrigation system for farmers

\begin{tabular}{cl|cccccc}
\hline \multicolumn{2}{c}{ Farm size groups } & Labour & Water Use & Irrigation cost & Quality & Productivity & Total cost \\
\hline \multirow{2}{*}{ I } & Average & 4.41 & 4.88 & 5.00 & 5.00 & 5.00 & 4.82 \\
& Minimum & 1.00 & 4.00 & 5.00 & 5.00 & 5.00 & 4.00 \\
& Maximum & 5.00 & 5.00 & 5.00 & 5.00 & 5.00 & 5.00 \\
\hline \multirow{2}{*}{ II } & Average & 5.00 & 4.92 & 4.92 & 4.85 & 4.69 & 4.54 \\
& Minimum & 5.00 & 4.00 & 4.00 & 4.00 & 4.00 & 1.00 \\
& Maximum & 5.00 & 5.00 & 5.00 & 5.00 & 5.00 & 5.00 \\
\hline \multirow{2}{*}{ III } & Average & 4.70 & 4.75 & 4.75 & 4.70 & 4.90 & 4.70 \\
& Minimum & 4.00 & 4.00 & 4.00 & 4.00 & 4.00 & 3.00 \\
\hline \multirow{2}{*}{ IV } & Maximum & 5.00 & 5.00 & 5.00 & 5.00 & 5.00 & 5.00 \\
& Average & 4.76 & 4.65 & 4.88 & 4.88 & 5.00 & 5.00 \\
& Minimum & 2.00 & 2.00 & 3.00 & 4.00 & 5.00 & 5.00 \\
\multirow{2}{*}{ FA } & Maximum & 5.00 & 5.00 & 5.00 & 5.00 & 5.00 & 5.00 \\
\hline
\end{tabular}

Table 3 Factors influencing the material selection for irrigation system

\begin{tabular}{cl|ccccc}
\hline Farm & size groups & Experience & Relatives & Technical staff & Written sources & Suppliers - Dealers \\
\hline \multirow{2}{*}{ I } & Average & 4.12 & 4.24 & 3.12 & 4.06 & 3.12 \\
& Minimum & 1.00 & 3.00 & 1.00 & 1.00 & 1.00 \\
& Maximum & 5.00 & 5.00 & 5.00 & 5.00 & 5.00 \\
\hline \multirow{2}{*}{ II } & Average & 4.69 & 3.46 & 3.69 & 3.54 & 2.54 \\
& Minimum & 4.00 & 1.00 & 1.00 & 1.00 & 1.00 \\
& Maximum & 5.00 & 5.00 & 5.00 & 5.00 & 2.00 \\
\hline \multirow{2}{*}{ III } & Average & 4.65 & 3.75 & 2.60 & 2.50 & 1.00 \\
& Minimum & 4.00 & 1.00 & 1.00 & 1.00 & 5.00 \\
\hline \multirow{2}{*}{ IV } & Maximum & 5.00 & 5.00 & 5.00 & 5.00 & 2.65 \\
& Average & 4.53 & 3.65 & 2.88 & 3.41 & 1.00 \\
\hline \multirow{2}{*}{ FA } & Minimum & 2.00 & 2.00 & 1.00 & 1.00 & 5.00 \\
& Maximum & 5.00 & 5.00 & 5.00 & 5.00 & 2.73 \\
\hline
\end{tabular}


Table 4 Farmers view of water

\begin{tabular}{|c|c|c|c|c|c|c|}
\hline \multicolumn{2}{|c|}{ Farm size groups } & $\begin{array}{c}\text { There is water } \\
\text { problem }\end{array}$ & $\begin{array}{l}\text { There will be water } \\
\text { problem in the future }\end{array}$ & $\begin{array}{l}\text { Water is } \\
\text { scarce }\end{array}$ & $\begin{array}{c}\text { Water is very } \\
\text { valuable }\end{array}$ & $\begin{array}{l}\text { Water resources } \\
\text { are diminishing }\end{array}$ \\
\hline \multirow{3}{*}{ I } & Average & 3.82 & 3.59 & 4.41 & 5.00 & 4.29 \\
\hline & Minimum & 1.00 & 1.00 & 1.00 & 5.00 & 2.00 \\
\hline & Maximum & 5.00 & 5.00 & 5.00 & 5.00 & 5.00 \\
\hline \multirow{3}{*}{ II } & Average & 4.00 & 4.23 & 4.31 & 4.92 & 4.85 \\
\hline & Minimum & 1.00 & 1.00 & 1.00 & 4.00 & 4.00 \\
\hline & Maximum & 5.00 & 5.00 & 5.00 & 5.00 & 5.00 \\
\hline \multirow{3}{*}{ III } & Average & 4.35 & 4.65 & 4.05 & 5.00 & 4.65 \\
\hline & Minimum & 1.00 & 3.00 & 1.00 & 5.00 & 1.00 \\
\hline & Maximum & 5.00 & 5.00 & 5.00 & 5.00 & 5.00 \\
\hline \multirow{3}{*}{ IV } & Average & 3.59 & 3.53 & 3.59 & 4.94 & 4.24 \\
\hline & Minimum & 1.00 & 1.00 & 1.00 & 4.00 & 1.00 \\
\hline & Maximum & 5.00 & 5.00 & 5.00 & 5.00 & 5.00 \\
\hline \multirow{3}{*}{ FA } & Average & 3.96 & 4.01 & 4.07 & 4.97 & 4.49 \\
\hline & Minimum & 1.00 & 1.00 & 1.00 & 4.00 & 1.00 \\
\hline & Maximum & 5.00 & 5.00 & 5.00 & 5.00 & 5.00 \\
\hline
\end{tabular}

Table 5 The water use knowledge of farmers

\begin{tabular}{|c|c|c|c|c|c|}
\hline \multirow{2}{*}{ Reaction to the different statements about water use } & \multicolumn{4}{|c|}{ Farm size groups } & \multirow{2}{*}{ FA } \\
\hline & $\mathrm{I}$ & II & III & IV & \\
\hline Water is mostly used in agriculture & 4.35 & 3.62 & 4.65 & 4.35 & 4.30 \\
\hline Unconscious irrigation is done & 4.12 & 4.23 & 3.15 & 3.06 & 3.58 \\
\hline New irrigation method provides savings & 4.65 & 4.92 & 4.75 & 4.82 & 4.78 \\
\hline Producers should join farms & 4.82 & 4.62 & 4.80 & 4.88 & 4.79 \\
\hline Producers should protect the supply network & 4.82 & 5.00 & 4.85 & 4.59 & 4.81 \\
\hline Water should not be wasted & 4.88 & 4.85 & 4.70 & 4.88 & 4.82 \\
\hline I warn in case of the wasted water & 4.82 & 4.69 & 4.60 & 4.82 & 4.73 \\
\hline Plenty of water increases diseases and pests & 4.41 & 4.62 & 4.75 & 4.76 & 4.64 \\
\hline I know the water consumption of plants & 3.59 & 4.08 & 4.50 & 4.82 & 4.27 \\
\hline I know the time of irrigation & 3.94 & 4.69 & 4.70 & 4.88 & 4.55 \\
\hline I know the irrigation system suitable to my field & 3.59 & 3.77 & 3.70 & 4.24 & 3.82 \\
\hline I do constrained irrigation if necessary & 3.65 & 3.31 & 3.55 & 3.29 & 3.46 \\
\hline Plenty of water is good for productivity & 1.82 & 1.62 & 1.40 & 1.59 & 1.60 \\
\hline Over water use does not damage the soil & 2.12 & 1.15 & 1.10 & 1.29 & 1.42 \\
\hline Surface irrigation is the best method & 1.12 & 1.08 & 1.00 & 1.12 & 1.07 \\
\hline
\end{tabular}

Table 6 Evaluation of some factors for water saving

\begin{tabular}{l|ccccc}
\hline \multicolumn{1}{c|}{ Water saving factors } & \multicolumn{4}{c}{ Farm size groups } \\
\cline { 2 - 5 } FA \\
\cline { 2 - 5 } Planned water distribution & I & II & III & IV & 4.70 \\
Training & 4.82 & 4.69 & 4.65 & 4.65 & 4.60 \\
Application of technology to agriculture & 4.76 & 4.69 & 4.40 & 4.59 & 4.61 \\
Increasing control mechanism & 4.76 & 4.77 & 4.50 & 4.47 & 4.42 \\
Placing recorders at the beginning of parcels & 4.59 & 4.38 & 4.65 & 4.00 & 4.12 \\
Legal punishments & 4.76 & 4.15 & 4.00 & 3.59 & 4.12 \\
Increasing irrigation water price & 3.59 & 3.46 & 4.20 & 3.59 & 3.75 \\
\hline
\end{tabular}

\section{Paid Water Prices and Preferences}

The water prices that farmers paid were determined for all survey conducted farms according to the farm size groups. The water price per farm groups was $14.41 € / \mathrm{da}$ in group I enterprise, $11.92 \mathrm{E} / \mathrm{da}$ in group II enterprise, $8.20 \mathrm{E} / \mathrm{da}$ in group III enterprise, $19.65 \mathrm{\Xi} / \mathrm{da}$ in group IV enterprise. The water price was $13.40 \mathrm{\xi} / \mathrm{da}$ at the farms average. According to the evaluation of those paying water price, the evaluation point was 2.83 in group I enterprise, 3.00 in group II enterprise, 2.67 in group III enterprise, 2.91 in group IV enterprise and farmers found the water prices high. Farmers paid 38.04 e per decare in the research field (Table 7).

The farmers were asked the betterment of irrigation system and the price they were willing to pay with 5 multiple choices. The answers were (0), I do not pay 
additional rate and (1), I pay 1-30 $\mathrm{\text { }} / \mathrm{da}$. The additional price that farmers were willing to pay was $22.94 \mathrm{E} / \mathrm{da}$ in group I, $20.77 € /$ da in group II, $24.00 € /$ da in group III and $21.18 \mathrm{E} / \mathrm{da}$ for group IV according to the farm size groups' average, respectively. The average price was calculated as $22.39 € /$ da (Table 8 ).

$25 \%$ of the farmers do not accept to pay additional money and $75 \%$ accept to pay additional money (Figure 1).

\section{Logit Analysis}

Before the analysis, the optimum variables, which explain farmers' behaviours regarding the willingness to pay additional rate in the best way, were determined.
Socio-demographic, economic, behavioural variables influence farmers' willingness to pay additional rate. Logistic regression model was calculated with standard (enter) method. The explanatory variables for farmers' willingness to pay additional rate were given at Table 9 . Variables' definitions, average and standard deviation values were given at Table 9 and Table 10.

Logistic regression does not consider about the estimate of dependent variable value. It aims to estimate the possibility of dependent variable's being 1 or the possibility of tested variable's actualization. As the obtained result was a possibility value, it can only take 0 and 1 values (Alpar, 2013).

Table 7 Water price and evaluation

\begin{tabular}{l|ccc}
\hline Farm size groups & Average of those paying water price (£/da) & Average water price (£/da) & Water price evaluation \\
\hline I & 40.83 & 14.41 & 2.83 \\
II & 38.75 & 11.92 & 3.00 \\
III & 27.33 & 8.20 & 2.67 \\
IV & 30.36 & 19.65 & 2.91 \\
FA & 33.26 & 13.40 & 2.85 \\
AO & 38.04 & 13.04 & 2.85 \\
\hline
\end{tabular}

Table 8 The possible additional water price

\begin{tabular}{|c|c|c|c|}
\hline & Farm size groups & Water price preference & Price for preference $(€ / \mathrm{da})$ \\
\hline \multirow{2}{*}{ I } & Average & 1.76 & 22.94 \\
\hline & Standard error & 0.44 & 13.12 \\
\hline \multirow{2}{*}{ II } & Average & 1.69 & 20.77 \\
\hline & Standard error & 0.48 & 14.41 \\
\hline \multirow{2}{*}{ III } & Average & 1.80 & 24.00 \\
\hline & Standard error & 0.41 & 12.31 \\
\hline \multirow{2}{*}{ IV } & Average & 1.71 & 21.18 \\
\hline & Standard error & 0.47 & 14.09 \\
\hline \multirow{2}{*}{ FA } & Average & 1.75 & 22.39 \\
\hline & Standard error & 0.44 & 13.15 \\
\hline
\end{tabular}

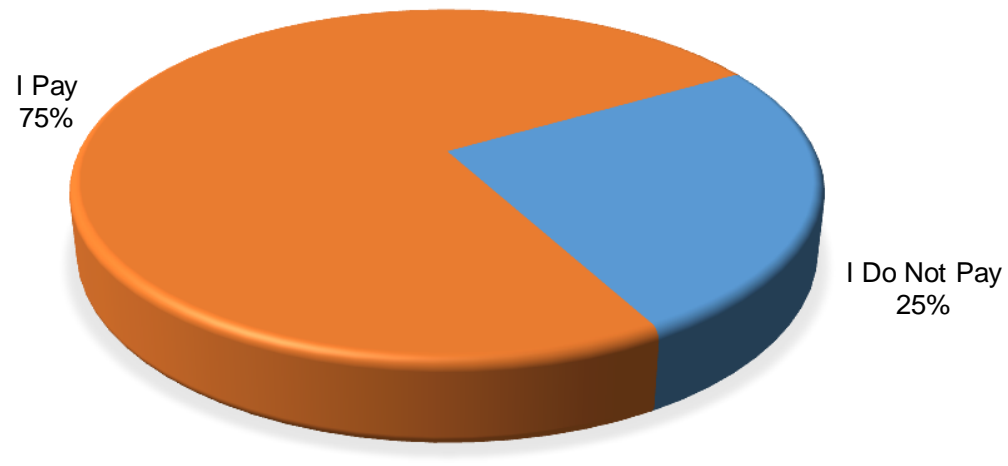

Figure 1 The farmers' opinions about paying additional water rate after the project 
Table 9 The explanatory statistics of variables in Logit model

\begin{tabular}{|c|c|c|c|c|}
\hline Variables & Explanation & Units & Average & $\mathrm{SE}$ \\
\hline ASAWR & Acceptance status of additional water rate & Yes: 1 ; No: 0 & 0.75 & 0.44 \\
\hline FAMILY & Household size & Number & 3.48 & 1.32 \\
\hline SUPPLY & Land ownership & Number & 83.84 & 81.49 \\
\hline $\mathrm{CO}$ & Computer ownership & Yes: 1 ; No: 0 & 0.27 & 0.45 \\
\hline OD1 & Operating debt per decare & Number & 148.44 & 245.38 \\
\hline NRS & Newspaper reading status & Reading:1; Not reading:2 & 0.43 & 0.50 \\
\hline SCS & Social security status & $\begin{array}{l}\text { social security organization for } \\
\text { artisans and the self- } \\
\text { employed:1; SSI: } 2 \text {; Retired:3 }\end{array}$ & 2.12 & 0.93 \\
\hline SPWP & Status of paying water price & Paying: 1; Not paying: 0 & 0.40 & 0.49 \\
\hline AI & Agricultural income per decare & Number & 252.99 & 301.72 \\
\hline FEL & Farmers' education level & $\begin{array}{l}\text { Primary school - literate: } 1 \text {; } \\
\text { Secondary school: } 2 \text {; High } \\
\text { school- College: } 3\end{array}$ & 1.93 & 0.89 \\
\hline AT & Agricultural training & Yes: 1 ; No: 0 & 0.15 & 0.36 \\
\hline FAE & Farmers' agricultural experience & Number & 27.27 & 12.31 \\
\hline MPU & Membership of producer unions or cooperative & Number & 13.81 & 12.81 \\
\hline
\end{tabular}

SE: Standard error

Table 10 Variables found at the start model

\begin{tabular}{|c|c|c|c|c|}
\hline \multirow{3}{*}{\multicolumn{2}{|c|}{ Real/Observed situation }} & \multicolumn{3}{|c|}{ Estimated situation } \\
\hline & & \multicolumn{2}{|c|}{ Water price } & \multirow{2}{*}{ Percentage of correct classifying } \\
\hline & & I do not pay (0) & I pay $(1)$ & \\
\hline \multirow{2}{*}{ Additional water price } & I do not pay (0) & 0 & 17 & 0.00 \\
\hline & I pay (1) & 0 & 50 & 100.00 \\
\hline \multicolumn{2}{|c|}{ Percentage of total correct classifying } & & & 74.63 \\
\hline \multicolumn{2}{|c|}{ Statistics of fixed value } & & & \\
\hline B. & 1.08 & & & \\
\hline Standard error & 0.28 & & & \\
\hline Wald & 14.77 & & & \\
\hline sd & 1.00 & & & \\
\hline $\mathrm{P}$ & 0.00 & & & \\
\hline $\operatorname{Exp}(B)$ & 2.94 & & & \\
\hline
\end{tabular}

In the study, likelihood Ratio (LR) hypothesis test was used to test the logit model's acceptability of general meaningfulness statistically and explanatoriness of the obtained equation. According to this hypothesis test;

LR=-2[(LogLikelihood constrained)-(LogLikelihood unconstrained)]

$$
\mathrm{LR}=-2[(-41.659)-(-75.897)]
$$

$\mathrm{LR}=68.476$

Considering the constrained and unconstrained loglikelihood values, LR value obtained in the model was bigger than 23.68 which equals $\chi^{2}(14)$ critical value at $5 \%$ level (68.476). In the study, likelihood Ratio (LR) hypothesis test result indicates the Logit model's acceptability of general meaningfulness statistically and supports explanatoriness of the obtained equation.

Estimated model was indicated as;

$\mathrm{ASAWR}=\mathrm{f}$ (FAMILY, SUPPLY CO, OD1, NRS, SPWP, AI, FEL, AT, FAE, MPU) (Table 9).
The variables, which were not found at the start model of willingness to pay additional rate, were independent variables of the model (Table 10).

Whether the variables, which were not found in the start model, have meaningful contribution to willingness to pay additional water rate or whether the model was statistically meaningful were measured by error chisquare statistics $\left(\chi^{2 \beta}\right)$ in logistic regression model. These values being meaningful indicates that the coefficients regarding the independent (explanatory) variables, which were not found in the model, were meaningfully different from zero (0) (Çokluk, et al. 2014). The error chi-square value regarding the socioeconomic variables chosen to be added to the model was found to be $\left[\chi^{2 \beta_{0}}=26.58, \mathrm{p}<0.05\right]$ (Table 11). One or more of the variables chosen to be added to the model will have favourable contributions to the explanation of willingness to pay additional water rate.

Regarding the coefficients found statistically meaningful at the significance level according to farmers' socioeconomic features' influence on the possibility to paying additional water rate; positive coefficient variables 
increased the possibility to pay water price and negative coefficient variables decreased the possibility to pay additional water rate.

In the logit model, such socioeconomic features of farmers as household size, computer ownership, paid irrigation water price, education time had a positive and statistically meaningful relationship with the willingness to pay additional water rate. According to the result obtained, the changes on these variables, which represent the socioeconomic variables of farmers partially, would create positive effect on willingness to pay additional water rate (Table 12).

On the other hand, such socioeconomic features of farmers as operating debt per decare, agricultural training status, and agricultural experience time had a negative and statistically meaningful relationship with the willingness to pay additional water rate. The changes on the negative coefficient, statistically meaningful socioeconomic variables would create negative effect on willingness to pay additional water rate (Table 12).

The exponential coefficients, Exp (B)s of the model were the logarithm of original coefficients. It means that exponential coefficients cannot be negative. The exponential coefficients' being over 1 refers to the positive original coefficient and the exponential coefficients' being below 1 refers to the negative original coefficient (Alpar, 2013).

Under the condition that other variables were fixed, the value of exponential coefficient $\operatorname{Exp}(\mathrm{Bi})$ indicates how many times more the dependent variable $(\mathrm{Y})$ can be observed with the effect of independent variable (Xi) or how much its percentage to be observed increased (Özdamar, 2013).

At the end of the logit model, such socioeconomic features of farmers chosen to estimate the possibility of farmers' willingness to pay additional water rate as household size, computer ownership, paid irrigation water price, education time, operating debt per decare, agricultural training status, and agricultural experience were found to be statistically meaningful.

Table 11 Variables which were not found at the start model
The explanatory variables were believed to explain the model well thanks to model's being statistically meaningful and having a high safe estimate ratio.

The increase in household size and household's male labour force increased the possibility to pay additional water rate by 2.66 times. It was pointed out that there was a statistically meaningful relationship between farmers' having computer and possibility to pay additional water rate. As farmers' computer ownership increased, the possibility to pay additional water rate increased. It was seen that the expectation of farmers, who already pay water price, for the renovation of irrigation system and use of modern irrigation system will have a positive effect on the possibility to pay additional water rate. The expectation of farmers, who already pay water price, for the renovation of irrigation system and use of modern irrigation system increases the possibility to pay additional water rate by 16.61 times. The educational time of farmers was found to be statistically meaningful in all groups. Having a secondary school diploma increases the possibility to pay additional water rate by 116.74 times and high school - college diploma by 106.30 times respectively (Table 12).

The farmers' debt per decare decreases the possibility to pay additional water rate. The increase in debt per decare decreased the possibility to pay additional water rate by 0.99 times. It was pointed out that there was a statistically meaningful relationship between farmers' agricultural training and possibility to pay additional water rate. The farmers' having agricultural training decreased the possibility to pay additional water rate by 0.08 times. There was a negative relationship between production time and possibility to pay additional water rate. The production time decreased the possibility to pay additional water rate by 0.85 times (Table 12).

As there was not a statistically meaningful relationship between farmers' land ownership, newspaper reading status, social security, agricultural income per decare, membership time to agricultural cooperation and possibility to pay additional water rate, comment was avoided (Table 12).

\begin{tabular}{l|ccc}
\hline \multicolumn{1}{c|}{ Variables } & Score & sd & P \\
\hline FAMILY & 1.21 & 1 & 0.27 \\
SUPPLY & 0.01 & 1 & 0.91 \\
CO & 0.99 & 1 & 0.32 \\
OC1 & 9.45 & 1 & 0.00 \\
NRS & 0.04 & 1 & 0.84 \\
SCS & 0.85 & 2 & 0.65 \\
SCS1 & 0.61 & 0.44 \\
SCS2 & 0.05 & 1 & 0.82 \\
SPWP & 4.86 & 1 & 0.03 \\
AI1 & 0.96 & 1 & 0.71 \\
FEL & 1.74 & 1 & 0.42 \\
FEL1 & 0.04 & 2 & 0.84 \\
FEL2 & 1.15 & 1 & 0.28 \\
AT & 3.76 & 1 & 0.05 \\
FAE & 1.86 & 1 & 0.17 \\
MPU & 0.34 & 1 & 0.56 \\
Error chi-square statistics $\left(\chi^{2 \beta}{ }_{0}\right)$ & 26.58 & 1 & 0.02 \\
\hline
\end{tabular}


Table 12 Coefficient estimates of aimed model variables

\begin{tabular}{|c|c|c|c|c|c|c|}
\hline Variables & B. & Standard error & Wald & $\overline{\mathrm{sd}}$ & $\bar{P}$ & $\operatorname{Exp}(B)$ \\
\hline FAMILY & 0.98 & 0.51 & 3.64 & 1.00 & 0.05 & 2.66 \\
\hline SUPPLY & -0.00 & 0.00 & 0.25 & 1.00 & 0.62 & 0.99 \\
\hline $\mathrm{CO}$ & 3.74 & 1.71 & 4.79 & 1.00 & 0.03 & 42.08 \\
\hline $\mathrm{OC} 1$ & -0.00 & 0.00 & 3.83 & 1.00 & 0.05 & 0.99 \\
\hline NRS & -1.04 & 1.08 & 0.93 & 1.00 & 0.33 & 0.35 \\
\hline SCS & & & 2.32 & 2.00 & 0.31 & \\
\hline SCS1 & -1.62 & 1.57 & 1.06 & 1.00 & 0.30 & 0.20 \\
\hline $\mathrm{SCS} 2$ & 1.62 & 1.74 & 0.87 & 1.00 & 0.35 & 5.06 \\
\hline SPWP & 2.81 & 1.37 & 4.21 & 1.00 & 0.04 & 16.61 \\
\hline AI1 & 0.00 & 0.00 & 1.00 & 1.00 & 0.32 & 1.00 \\
\hline FEL & & & 5.44 & 2.00 & 0.06 & \\
\hline FEL1 & 4.76 & 2.07 & 5.29 & 1.00 & 0.02 & 116.74 \\
\hline FEL2 & 4.66 & 2.32 & 4.05 & 1.00 & 0.04 & 106.30 \\
\hline AT & -2.58 & 1.22 & 4.46 & 1.00 & 0.03 & 0.08 \\
\hline FAE & -0.16 & 0.07 & 5.03 & 1.00 & 0.02 & 0.85 \\
\hline MPU & 0.05 & 0.05 & 1.11 & 1.00 & 0.29 & 1.05 \\
\hline Fixed & -0.95 & 2.00 & 0.22 & 1.00 & 0.63 & 0.39 \\
\hline$(-2 \mathrm{LL})$ & \multirow{3}{*}{\multicolumn{6}{|c|}{$\begin{array}{c}41.65 \\
0.59 \\
0.40\end{array}$}} \\
\hline Nagelkerke $\mathrm{R}^{2}$ & & & & & & \\
\hline Cox \& Snell R & & & & & & \\
\hline
\end{tabular}

Table 13 The classification table obtained from the Logit model

\begin{tabular}{|c|c|c|c|}
\hline \multirow{3}{*}{ Real/Observed situation } & \multicolumn{3}{|c|}{ Estimated situation } \\
\hline & \multicolumn{2}{|c|}{ Water price } & \multirow{2}{*}{$\begin{array}{c}\text { Percentage of } \\
\text { correct classifying }\end{array}$} \\
\hline & I do not pay (0) & I pay (1) & \\
\hline \multirow{3}{*}{$\begin{array}{ll}\text { Water price } & \text { I do } \\
\text { Percentage of total correct classifying }\end{array}$} & 11 & 6 & 64.70 \\
\hline & 2 & 48 & 96.00 \\
\hline & & 88.10 & \\
\hline
\end{tabular}

The logit model was used in order to for the analysis of the influence of socioeconomic factors influencing farmers' willingness to pay additional water rate on the possibility to pay additional water rate and the model's safe estimate ratio was calculated as $88.10 \%$ (Table 13 ). The shadow certainty coefficient was estimated as 0.59 (Table 12).

\section{Conclusion}

Irrigation system is remarkably effective on the labour, water use, irrigation cost, product quality productivity and total cost. The recommendations of technical staff, written sources and dealers have low influence on material selection.

Farmers consider water as very valuable, as it directly affect their income besides meeting daily needs. They express that there is / will be a water problem in the region and they agree that water is scarce. At the same time, they believe that water resources were diminishing.

According to the results of cross questions asked to determine the knowledge and awareness level of farmers about the water use, it can be said that they have knowledge about the water consumption of the cultivated vegetables, irrigation time, irrigation time and system specific to the soil. They were extremely sensitive about the water saving and they agree that water should not be wasted, supply network should be protected, water saving should be increased through information exchange with the union managers.

The interviewed farmers think that water saving can be accomplished through planned water distribution, training and extension activities about irrigation, technological investments, increasing control activities of authorized institutions and placing recorder at the beginning of parcels.

The logit model was used in order to analyse the socioeconomic factors influencing farmers' willingness to pay additional water rate on the possibility to pay additional water rate and the model's safe estimate ratio was calculated as $88.10 \%$. It was found out that such socioeconomic features of farmers as household size, computer ownership, paid irrigation water price, education time had a positive have statistically meaningful relationship with the willingness to pay additional water rate. The increase in household size and household's male labour force increased the possibility to pay additional water rate by 2.66 times. The expectation of farmers for the renovation of irrigation system and use of modern irrigation system increases the possibility to pay additional water rate by 16.61 times. Having a secondary school diploma increases the possibility to pay additional water rate by 116.74 times and high school college diploma by 106.30 times, respectively.

On the other hand, such socioeconomic features of farmers as operating debt per decare, agricultural training 
status and farmers' agricultural experience had a negative and statistically meaningful relationship with the willingness to pay additional water rate. The increase in debt per decare decreased the possibility to pay additional water rate by 1.05 times, the farmers' having agricultural training decreased it by 0.08 times and experience decreased it by 0.85 times.

\section{Acknowledgement}

We would like to thank Suleyman Demirel University (Project number: SDÜ BAP 3648-YL1-13) for their financial support. This paper was presented at the International Conference on Conservation Agriculture and Sustainable Land Use (31 May-02 June, 2016, Hungary) and first published here.

\section{Authors' Contributions}

This study is a part of the Kutlan Uzunkaya's postgraduate thesis. Mevlüt Gül is a supervisor.

\section{References}

Alpar R. 2013. Uygulamalı Çok Değişkenli İstatistik Yöntemler. Detay Yayıncilık, Ankara.

Aydoğdu MH, Karlı B, Yenigün K, Mancı AR, Aydoğdu M. 2014 Tarımsal Sulamalarda Fiyatlandırma Eğilimleri; Çiftçilerin Fiyatlandırmaya Tutum ve Algıları; Gap-Harran Ovas Sulamaları, Şanliurfa. The Journal of Academic Social Science Studies, International Journal of Social Science, Doi Number: Http://Dx.Doi.Org/10.9761/Jasss2529, Number: 29, P. 165-188. Aydoğdu MH, Karlı B, Aydoğdu M. 2015. Sulama Birlik Başkanlarının Su Fiyatlandırması ve İşletmeciliğine Bakışları: Gap-Harran Ovas1 Sulamaları Örneklemesi. The Journal of Academic Social Science Studies, International Journal of Social Science, Doi Number: Http://Dx.Doi.Org/10.9761 /Jasss2694, 31: 167-177.
Çınar G, Armağan G. 2009. Üreticilerin Tarımsal Yayım ve Danışmanlık Hizmetleri İçin Ödemeye İstekli Oldukları Ücretlerin Belirlenmesi: Aydın İli Örneği. Tarım Ekonomisi Dergisi, 15(2): 83-92.

Çiçek A, Erkan O. 1996. Tarım ekonomisinde araştırma ve örnekleme yöntemleri. Gaziosmanpaşa Üniversitesi, Ziraat Fakültesi Yayınları No:12, Tokat.

Çokluk Ö, Şekercioğlu G, Büyüköztürk Ş. 2014. Sosyal Bilimler İçin Çok Değişkenli İstatistik Spss ve Lisrel Uygulamaları. Pegem Akademi, Ankara.

DSİ. 2013. Accessed date: 18.03.2013. web page: http://www.dsi.gov.tr/toprak-ve-su-kaynaklari.

Eren G, Bilgiç A, Karlı B, Miran B. 2008. Gap Bölgesinde Kaliteli İçme Suyunun Fiyatlandırmasına Etki Eden Faktörler. Tarım Ekonomisi Dergisi, 14(2): 67-74.

Gujarati DN, Porter D.C. 2009. Basic Econometrics 5th Edition. Mcgraw-Hill Education, USA.

Gül M, Akpınar MG, Dağıstan E. 2012. Meyve Suyu Tüketimi Konusunda Toplumsal Bilinç Düzeyi ve Optimum Ürün Tasarımının Analizi: Akdeniz Bölgesi Örneği, Tübitak Projesi Proje No: 110k085.

Kalaycı Ş, Albayrak AS, Eroğlu A, Küçüksille E, Ak B, Karaatlı M, Keskin EÜ, Çiçek E, Kayış A, Öztürk E, Antalyalı Ö.L, Uçar N, Demirgil H, İşler DB, Sungur O. 2005. SPSS Uygulamalı Çok Değişkenli İstatistik Teknikleri. Asil Yayın Dağıtım Ltd., İstanbul.

Özdamar K. 2013. Paket Programlar İle İstatistiksel Veri Analizi Cilt 1. Nisan Kitabevi, Eskişehir.

Yamane T. 2001. Temel örnekleme yöntemleri. Çevirenler: Esin, A., Aydın, C., Bakır, M.A., Gürbüzsel, E., Literatür Yayınları, 509 s, İstanbul. 